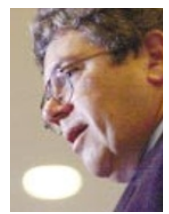

War of words

Biologist licks his wounds after stemcell débâcle p4

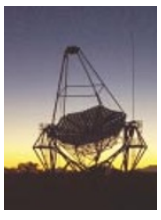

Looking up

Namibian telescope sees Africa join the hunt for cosmic rays p6

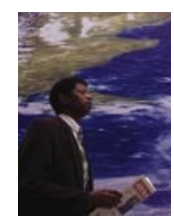

World view

Science has its say

at Johannesburg

conference

$\mathrm{p} 7$
Sold short

Original yardstick shows the metre is not long enough p8

\title{
Geneticists lay foundations for human transcriptome database
}

David Cyranoski, Tokyo

Move over genome, here comes the transcriptome. Last week, 120 researchers from around the world gathered in Tokyo to assemble the core of a transcriptome database, which they hope will one day hold all of the expressed sequences in the human genome.

The database, which should be up and running by December, will be a universal resource for biological research and drug discovery, say the meeting's organizers. "We want to know exactly where the genes are and what they do," says Sumio Sugano, a researcher from the University of Tokyo's Institute of Medical Science.

As the first step in producing proteins, information in genes is transcribed into messenger RNA (mRNA). This process separates the coding sequences of genes from the rest of the genome - often called 'junk' DNA. The transcriptome is the complete set of transcribed mRNA. For years, researchers have studied these transcripts in the form of complementary DNAs (cDNAs), which are made using the mRNA taken from cells as a template. cDNAs represent the mRNA present in the cell, but they are much easier to work with than mRNA itself.

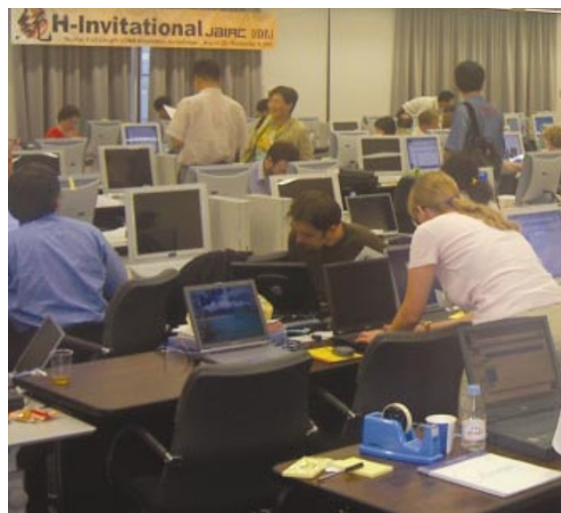

Expressed interest: researchers gathered in Tokyo to assess the integrity of cDNA data.

Now researchers want to incorporate the sequences of all of the human cDNAs into a single database, to be run by the Japan Biological Information Research Center in Tokyo and the DNA Data Bank of Japan (DDBJ) in Mishima. At the Tokyo meeting, researchers analysed cDNA data representing over 20,000 genes - covering more than half of the transcriptome - for inclusion in the database.

Trying to find genes within the human genome sequence often means guessing at

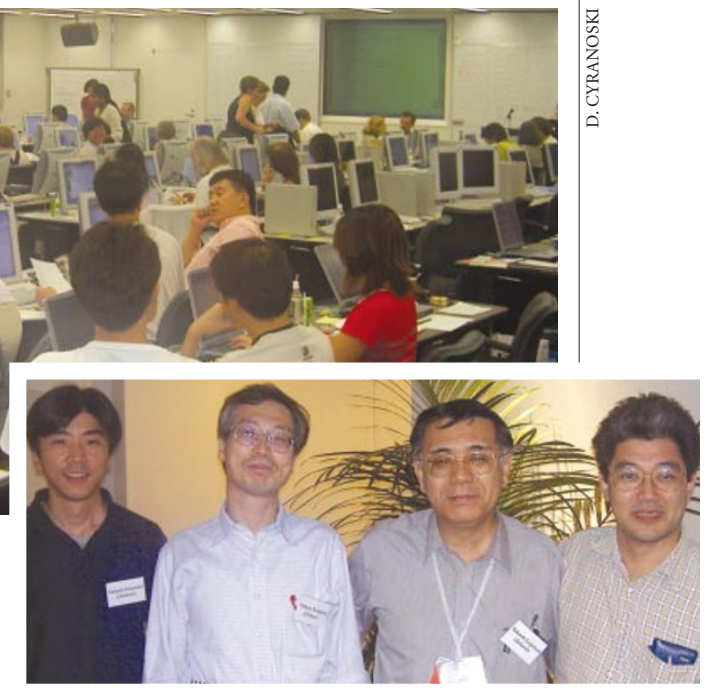

which parts are expressed by looking for certain patterns in the sequence. cDNAs, made from mRNA expressed in cells, offer a more direct route. "This will be a real humangene catalogue - not predicted from the human genome sequence. These are real transcripts," says meeting organizer Takashi Gojobori, director of the DDBJ in Mishima.

Most of the cDNAs are already publicly

\section{Bush urged to boost funding for physical sciences}

\section{Geoff Brumfiel, Washington}

The main scientific advisory panel to the White House has joined a chorus of calls for more research funding for the physical sciences in the United States.

In a letter soon to be sent to President George W. Bush, the President's Council of Advisors on Science and Technology (PCAST) will call for a funding increase in fields such as physics and engineering, to match the five-year doubling of biomedical research at the National Institutes of Health, which will be completed next year.

"All evidence points to a need to improve funding levels for physical sciences and certain areas of engineering," says a draft of the letter, which was discussed by PCAST on 29 August and is expected to be formally agreed and sent within a few days.

Because Bush appointed PCAST only last year, and it comprises scientists and engineers friendly to the administration, lobbyists are optimistic that Bush will heed its advice. "I think this letter is a breath of fresh air," says Michael Lubell, director of public affairs at the American Physical Society in Washington DC, which has advocated an increase for the past few years.

Lubell believes that the proposal will influence Bush and the Office of Management and Budget, which sets the president's annual budget - although he is not sure if it will influence the president's budget request for 2004, which is being drawn up now for release in February. "The 2004 presidential budget will be extraordinarily tight," he says.

Some scientific societies were less happy that the letter failed to mention other disciplines, such as space science and mathematics, whose funding has languished in recent years. "I'm a little concerned about the way they worded this letter," says Samuel Rankin, director of the American

Mathematical Society in Washington DC.

But Lubell says he doesn't think that these fields are being left out. "I think they are implicitly included," he says. 
available — but many exist as fragments of : the complete cDNA. In addition, the lack of : proper categorization, and inconsistencies between the various databases, limits the usefulness of the sequences for research.

"The data will be well-defined and quality controlled through the checks and balances of over a hundred scientists," says Ranajit Chakraborty, director of the Center for Genome Information at the University of Cincinnati Medical Center in Ohio.

To create the data set, the researchers mapped 42,000 cDNAs, collected from six databases around the world, to some 23,000 different regions on the human genome. The overlap of many cDNAs at the same regions will shed light on one of the mysteries of the genome - how so few genes can make the range of proteins that carry out the many functions in human development, and also produce so much variety in people's genetically determined features.

One explanation is that the genes undergo alternative splicing, whereby various mRNAs are produced from the same genomic sequence. By looking at many slightly different cDNAs that cover the same gene regions, researchers say that they will find many examples of these alternate forms of mRNA.

The meeting also offered a large data set, and a platform for debate, concerning non-coding RNA, which does not make protein. Some researchers believe such non-coding RNA has a major role in regulating gene expression, but the idea remains controversial (see Nature 418, 122-124; 2002).

www.jbirc.aist.go.jp/index_E.html

www.ddbj.nig.ac.jp

\section{Name-calling gets stem-cell researcher into hot water}

\section{Carina Dennis, Sydney}

If you ever find yourself called from the lab bench to testify on a contentious topic, here's a cautionary tale: a prominent stemcell researcher is this week licking his wounds after being accused of misleading the Australian public over the potential of embryonic stem-cell research.

Alan Trounson, who directs a developmental-biology centre at Monash University in Melbourne, has been widely denounced in the news media for a technical inaccuracy made during briefings to members of parliament. Opponents of the research rounded on the error as evidence that scientists were wilfully misrepresenting their findings.

"As a scientist whose integrity has been put at stake by people with an axe to grind, it has been terrible for me, and the impact on my family has been awful," says a drained Trounson, who was hospitalized last week for a heart condition.

Trounson showed parliamentarians a video of the recovery of a paralysed rat following injection of what he said were human embryonic stem cells. But the cells were embryonic germ cells — strictly speaking, cells from the parts of 5-9-week-old embryos and fetuses from which eggs and sperm later form. Embryonic stem cells are derived from embryos that are just a few days old. The video was taken at the lab of John Gearhart, a biologist at Johns Hopkins University, Baltimore, but the experiment's results have yet to be published.

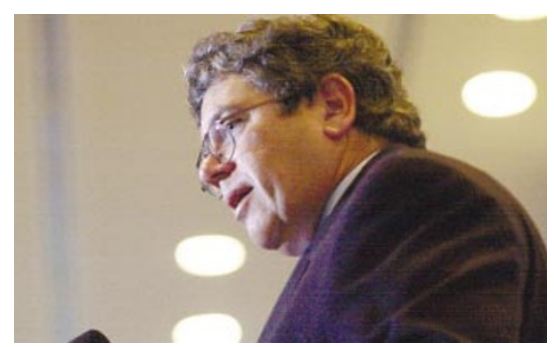

Tongue-tied: Alan Trounson's attempts to simplify science for parliament backfired in the media.

Although Trounson acknowledges the error, he defends his actions. "Embryonic germ cells had never been explained to these parliamentarians before, so I simplified and just called them embryonic stem cells," he says. "This is not absolutely correct, but they are embryonic and they are stem cells and you can't tell the difference between them."

Several biologists have jumped to Trounson's defence. But he advises others to step gingerly when providing information to politicians. "Be very careful about taking these matters forward unless you get a professional organization to help you, in terms of handling the media and the politics," he says. "You just can't do it yourself."

Australia is currently looking at legislation to regulate human cloning and stem-cell research. Last week, parliament voted to pass a blanket ban on human cloning and to defer the vote on embryonic stem-cell research untillater this month.

\section{Dispute over first authorship lands researchers in dock}

\section{Alison Abbott, Munich}

Rows about the order of authors' names on a research paper can get stormy at times but they don't often end up in court. That's what has happened, however, in a dispute between two molecular biologists at Germany's University of Göttingen.

The paper in question - an analysis of a tyrosine kinase receptor of relevance to cancer - had been jointly prepared by Marco Ledwon, a former PhD student at the university, and Frauke Alves, the leader of the research team, for submission to the journal Biological Chemistry.

But Ledwon, who now works for Lower Saxony's Association of Libraries, took legal action in February, before the paper was submitted, alleging that Alves had substituted her name for his as first author on the final draft without reasonable cause.
The state court of Lower Saxony slapped an immediate injunction on Alves to prevent her submitting the paper for publication

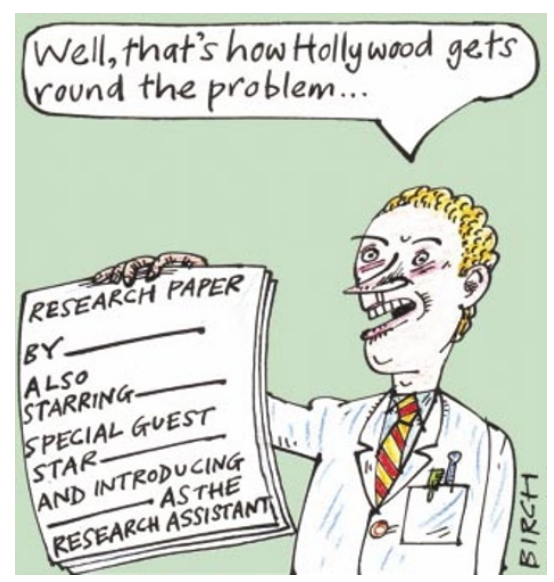

until the court had made a considered ruling.

A few weeks ago, the court ruled in favour of Ledwon. But it did not base its ruling on the relative intellectual contributions of Ledwon and Alves to the paper. Instead it said that the original verbal agreement that Ledwon should be first author had not been disputed in the 14 months during which the paper was being prepared. This understanding constituted an implicit contract, the court said, which Alves had broken.

According to Laborjournal, the magazine that first reported the case, Alves contends that Ledwon made insufficient research contribution to warrant first authorship. But Ledwon says he carried out experiments independently and helped to write the paper. The paper has not yet been submitted for publication and the University of Göttingen declined to comment on the case. 